\title{
Managing Non-Technical Requirements in COTS Components Selection
}

\author{
Juan Pablo Carvallo ${ }^{1}$, Xavier Franch ${ }^{2}$, Carme Quer ${ }^{2}$ \\ ${ }^{1}$ ETAPATELECOM (Cuenca, Ecuador) \\ ${ }^{2}$ Universitat Politècnica de Catalunya (Barcelona, Spain) \\ jpcarvallo@etapatelecom.net, \{franch,cquer\}@lsi.upc.edu
}

\begin{abstract}
The selection of COTS components is made not only by an analysis of their technical quality but also (and sometimes mostly) by considering how they fulfill those non-technical requirements considered relevant, which refer to licensing, reputation, and similar issues. In this paper we present an approach for managing nontechnical requirements during COTS selection. The proposal is based on extending the ISO/IEC 9126-1 catalogue of quality factors by adding factors related to non-technical issues, obtaining a cohesive and comprehensive framework for managing requirements during selection.
\end{abstract}

\section{Introduction}

The increasing use of Commercial Off-The-Shelf (COTS) components in both public and private companies has brought several new challenges to the software engineering community. Among them, the selection of COTS components (hereafter, COTS selection) remains particularly challenging. COTS selection embraces several activities [1]: the elicitation of the appropriated requirements; the localization and understanding of available components; and the assessment of the quality of those components in relation to the requirements.

Although non-technical requirements have been considered relevant in the establishment of the basic criteria for COTS component evaluation [2, 3, 17], most of the work in relation to COTS selection has focused in the technical aspects of quality, and not to non-technical issues [4]. Thus, the analysis of nontechnical aspects of COTS components, their categoryzation and their representation is more than justified.

In this paper we tackle this issue. Our proposal is based on the belief that technical and non-technical aspects shall be dealt similarly during COTS selection. Therefore, we propose to extend the ISO/IEC 9126-1 catalogue of quality factors [5] with non-technical factors following the same layout as in this standard.

Our research has combined action-research through different industrial experiences (see table 1) with literature survey.

\section{Extending the ISO/IEC 9126-1 Framework with Non-Technical Factors}

The main idea behind the ISO/IEC 9126-1 standard is to use quality models, composed of three types of quality factors (characteristics, subcharacteristics and attributes), as a framework for software evaluation. The standard fixes a set of six technical characteristics (functionality, reliability, usability, efficiency, maintainability and portability) decomposed into a first level of subcharacteristics (such as security, portability, etc). All these quality factors are intended for the evaluation of the technical quality of software, without mention or support the evaluation of non-technical quality aspects.

In our proposal we arrange non-technical attributes in an ISO/IEC 9126-1 tree-like structure, thus the catalogues that we use for COTS selection include high-level characteristics and subcharacteristics, and also lower-level attributes.

We distinguish 3 different catalogues (see figure 1): 1) NT-ISO/IEC catalogue. Defines the two highest levels of the hierarchy. This catalogue is equivalent to the ISO/IEC catalogue for non-technical quality factors.

2) Extended NT-ISO/IEC catalogue. It is an intermediate, highly reusable catalogue that includes non-technical subcharacteristics and attributes that are common in most COTS selection processes. This catalogue is the counterpart of the catalogue we proposed for technical factors [6] that we call extended ISO/IEC catalogue which adds 60 quality factors to the ISO/IEC 9126-1 standard.

3) Customized NT-ISO/IEC catalogue. It is a refinement of the previous catalogue to be used in a particular selection project. Usually, it decomposes some factors into others, adds new ones, and hides others that are not relevant for the problem at hand.

The design principles used for building these catalogues may be found at [12]. Also, the 6-step method presented in $[7,8]$ for building quality models has been adopted whenever possible. 


\begin{tabular}{|c|c|c|c|c|}
\hline Domain & $\begin{array}{c}\text { No. } \\
\text { Cases }\end{array}$ & Description & Size of QM & Participation \\
\hline \multirow{2}{*}{$\begin{array}{l}\text { Mail Servers } \\
{[7,8]}\end{array}$} & \multirow{2}{*}{2} & $\begin{array}{l}\text { CASE 1: } \\
\text { Organization Type: Public - Government } \\
\text { Expected Users: } 50000 \text { Local } \\
\text { - Main Project Budget: N/A } \\
\text { - Objective: Improve internal communication and support to citizens }\end{array}$ & \multirow{2}{*}{$\begin{array}{l}-410 \mathrm{QF} \\
5 \mathrm{Levels} \\
\\
1 \mathrm{QM}\end{array}$} & $\begin{array}{l}\text { Type of participation: Off-line } \\
\text { Timing: Post mortem } \\
\text { Objective: Validation of the process } \\
\text { Role: Observation }\end{array}$ \\
\hline & & $\begin{array}{l}\text { CASE 2: } \\
\text { Organization Type: Private-ISP } \\
\text { - Expected Users: } \approx 2000 \text { World Wide } \\
\text { - Main Project Budget: } 5000 \text { Eur. } \\
\text { - Objective: Provide e-mail services and discussion list to registered users }\end{array}$ & & $\begin{array}{l}\text { Type of participation: On-line } \\
\text { Timing: Project live } \\
\text { Objective: Provide evaluation criteria } \\
\text { Role: Observation }\end{array}$ \\
\hline $\begin{array}{l}\text { Requirement } \\
\text { Management } \\
\text { Tools [9] }\end{array}$ & 1 & $\begin{array}{l}\text { Organization Type: Public - Education } \\
\text { Expected Users: } 2-5 \text { members of project team } \\
\text { Main Project Budget: } 6^{\prime} 000.000 \text { Eur. } \\
\text { Objective: Manage project requirements }\end{array}$ & $\begin{array}{l}-329 \mathrm{QF} \\
-6 \text { Levels } \\
1 \mathrm{QM}\end{array}$ & $\begin{array}{l}\text { Type of Participation: On-line } \\
\text { Timing: Project kick-off } \\
\text { Objective: Select more suitable component } \\
\text { Role: Decision making }\end{array}$ \\
\hline $\begin{array}{l}\text { Workflow } \\
\text { [10] }\end{array}$ & 1 & $\begin{array}{l}\text { Organization Type: Public - Education } \\
\text { Expected Users: } 100-1000 \text { Administrative staff, campus wide, cross-campus. } \\
\text { Main Project Budget: 6'000.000 Eur } \\
\text { Objective: Improve management of medium and long lasting processes (regulations } \\
\text { approval, curricula) }\end{array}$ & $\begin{array}{l}-102 \mathrm{QF} \\
-3 \mathrm{Levels} \\
1 \mathrm{QM}\end{array}$ & $\begin{array}{l}\text { Type of Participation: On-line } \\
\text { Timing: Project development } \\
\text { Objective: Select more suitable component } \\
\text { Role: Decision making }\end{array}$ \\
\hline $\begin{array}{l}\text { Academic } \\
\text { Records } \\
\text { Management } \\
\text { System }\end{array}$ & 1 & $\begin{array}{l}\text { Organization Type: Public - Education } \\
\text { Expected Users: } 25000 \text {. } \\
\text { Main Project Budget: 6'000.000 Eur. } \\
\text { Objective: Improve management of internal documents, students registration and } \\
\text { records, teachers-students interaction etc. }\end{array}$ & $\begin{array}{l}\text { 120 QF } \\
\text { (Functional } \\
\text { only) } \\
5 \text { Levels } \\
1 \mathrm{QM}\end{array}$ & $\begin{array}{l}\text { Type of Participation: On-line } \\
\text { Timing: Project wrap-up } \\
\text { Objective: Documentation of final product } \\
\text { Role: Describe functional aspects of the } \\
\text { resulting system }\end{array}$ \\
\hline $\begin{array}{l}\text { IP Telephony } \\
\text { System } \\
\text { [11] }\end{array}$ & 1 & $\begin{array}{l}\text { Organization Type: Public - Telecommunication } \\
\text { Expected Users: } 100000 \text {. } \\
\text { Main Project Budget: USD } \$ 10^{\prime} 000.000 \\
\text { Objective: Provide public and domestic telephony services }\end{array}$ & $\begin{array}{l}1832 \mathrm{QF} \\
-4 \text { Levels } \\
-5 \mathrm{QM}\end{array}$ & $\begin{array}{l}\text { Type of Participation: On-line (ongoing) } \\
\text { Timing: Project life } \\
\text { Objective: Selection of more suitable } \\
\text { components } \\
\text { Role: Decision making }\end{array}$ \\
\hline
\end{tabular}

Table 1: Summary of industrial experiences in COTS selection (QF: quality factor; QM: quality model).

\subsection{The NT-ISO/IEC Catalogue}

The non-technical quality characteristics that we have included in the NT-ISO/IEC catalogue correspond to the main non-technical aspects often cited in the literature $[2,13]$.

These characteristics are three: Supplier, Business, and Product, and they group non-technical quality factors required to measure respectively: the supplier capability to address and support the project; the aspects related with the acquisition of the COTS component; and the out-of-the-box quality and effort required to get the component running.

In the second level we have included 15 subcharacteristics (see table 2). Some of them have also been identified in the literature (e.g. the Supplier/ Reputation subcharacteristic which corresponds to the Vendor Issues/Vendor Reputation factor included in
[13]), while others have been included to leverage the hierarchy grouping related lower-level attributes found. One subcharacteristic is decomposed later in the paper.

\subsection{The Extended NT-ISO/IEC Catalogue}

The extended NT-ISO/IEC catalogue [6] adds 126 non-technical quality factors to the 18 starting ones. In the following we explain situations that have occurred during the construction related to each type of element in the quality models.

Subcharacteristics. We have decomposed some subcharacteristics into others for structuring or leveraging purposes. This is the case of the Supplier/Organizational Structure subcharacteristic, which has been decomposed into Internal Structure and External Structure.

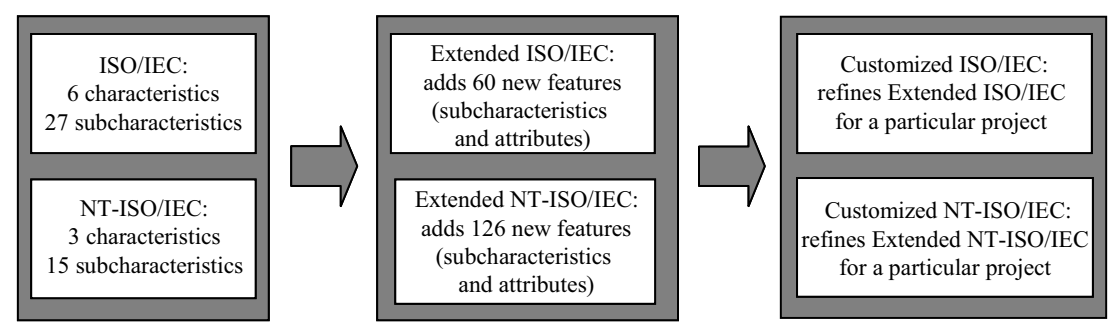

Figure 1: Three types of ISO/IEC-9126-1-based technical and non-technical catalogues. 


\begin{tabular}{|c|c|}
\hline \multicolumn{2}{|l|}{ Supplier } \\
\hline $\begin{array}{l}\text { Organizational } \\
\text { structure }\end{array}$ & $\begin{array}{l}\text { Description of the organizational structure of } \\
\text { the supplier company. }\end{array}$ \\
\hline $\begin{array}{l}\text { Positioning and } \\
\text { Strength }\end{array}$ & $\begin{array}{l}\text { Description of the position and orientation of } \\
\text { the supplier company in the market. }\end{array}$ \\
\hline Reputation & $\begin{array}{l}\text { Supplier's capability to perform similar } \\
\text { projects based on past experiences and } \\
\text { certifications. }\end{array}$ \\
\hline Services Offered & $\begin{array}{l}\text { Description of the services offered by the } \\
\text { supplier. }\end{array}$ \\
\hline Support & $\begin{array}{l}\text { Description of the support mechanisms offered } \\
\text { by the supplier. }\end{array}$ \\
\hline \multicolumn{2}{|l|}{ Business } \\
\hline $\begin{array}{l}\text { Licensing } \\
\text { Schema } \\
\end{array}$ & $\begin{array}{l}\text { Description of the COTS component licensing } \\
\text { options. }\end{array}$ \\
\hline Ownership & $\begin{array}{l}\text { Description of the aspects in relation to the } \\
\text { intellectual property rights. }\end{array}$ \\
\hline Guarantees & $\begin{array}{l}\text { Detail of the guarantees provided over the } \\
\text { product. }\end{array}$ \\
\hline Licensing Costs & $\begin{array}{l}\text { Description of the total cost of ownership for } \\
\text { the different licensing options available }\end{array}$ \\
\hline Platform Cost & $\begin{array}{l}\text { Estimation of the cost for the required } \\
\text { production platform }\end{array}$ \\
\hline $\begin{array}{l}\text { Implementation } \\
\text { Cost }\end{array}$ & $\begin{array}{l}\text { Estimation of implementation costs based on } \\
\text { similar past experiences. }\end{array}$ \\
\hline Network Cost & $\begin{array}{l}\text { Estimation of additional costs for network } \\
\text { operation. }\end{array}$ \\
\hline \multicolumn{2}{|l|}{ Product } \\
\hline History & $\begin{array}{l}\text { Aspects related with the evolution of the } \\
\text { product since it has been offered to the clients. }\end{array}$ \\
\hline Deliverables & $\begin{array}{l}\text { Detail of the out-of-the-box and expected post- } \\
\text { implementation deliverables. }\end{array}$ \\
\hline $\begin{array}{l}\text { Parameterization/ } \\
\text { Customization }\end{array}$ & $\begin{array}{l}\text { Description of the initial effort required for the } \\
\text { product to operate. }\end{array}$ \\
\hline
\end{tabular}

Table 2. NT-ISO/IEC catalogue.

Attributes. We have refined subcharacteristics into basic attributes, which are objectively measurable quality factors. One of them is the Total Number of Employees attribute categorized under the Internal Organization subcharacteristic mentioned above. We have also found derived attributes, which require to be additionally decomposed into other attributes. Among them we mention the Supplier/Positioning and Strength/Sales Forecast attribute. Among others its subattributes are Software Sales Forecast and Services Sales Forecast.

Metrics. In order to measure the attributes, metrics are required. They can be as simple as integer or boolean values or more complex as lists, records or functions. For derived attributes, sometimes it is not possible to find an objective metric to derive its value in terms of the attributes in which it is decomposed. In these cases subjective metrics are required. Some examples of metrics are shown in table 3 .

\begin{tabular}{|l|l|l|}
\hline \multicolumn{1}{|c|}{ Attribute } & \multicolumn{1}{c|}{ Metric } & \multicolumn{1}{c|}{ Example } \\
$\begin{array}{l}\text { Time of Product } \\
\text { in the Market }\end{array}$ & $\begin{array}{l}\text { Time: Ratio; } \\
\text { Time = Float[Years] }\end{array}$ & 5 years \\
\hline $\begin{array}{l}\text { Versions } \\
\text { Currently in the }\end{array}$ & $\begin{array}{c}\text { Versions: List (<Version: } \\
\text { Ordinal, Time: Ratio }>\text { ); } \\
\text { Mersion = (Unknown), } \\
\text { Time = Float[Months] }\end{array}$ & $\begin{array}{l}\text { V1, 8 months } \\
\text { V2, 9 months } \\
\text { V3, 3 months }\end{array}$ \\
\hline $\begin{array}{l}\text { Own Manu- } \\
\text { factured Product }\end{array}$ & $\begin{array}{l}\text { Own: Nominal; } \\
\text { Own = Label(Yes, Not) }\end{array}$ & Yes \\
\hline
\end{tabular}

Table 3. Sample non-technical attribute metrics.
Dependencies. Some quality factors depend on others, for instance the factor Supplier/Reputation is influenced by the factors Supplier/Positioning and Strength/ Incomes and Supplier/Support. The relationships found may be depicted by means of a tabular representation as proposed in [8].

Overlapping. Finally it is worth to remark that some non-technical quality attributes are suitable for the evaluation of other factors (either technical or not), thus overlapping is also supported in the approach. As an example we have that the Time of Product in the Market attribute decomposes the History non-technical subcharacteristic and this subcharacteristic decomposes the Maturity technical subcharacteristic of the original ISO/IEC 9126-1 quality standard.

An excerpt of the catalogue is included in Table 4.

\begin{tabular}{|c|c|c|c|c|}
\hline \multirow[t]{7}{*}{ Reputation } & \multicolumn{4}{|c|}{$\begin{array}{l}\text { Recognition of the capability of the supplier to perform similar } \\
\text { projects based on past experiences and certifications. }\end{array}$} \\
\hline & $\begin{array}{l}\text { Supplier Company } \\
\text { Existence }\end{array}$ & \multicolumn{3}{|c|}{$\begin{array}{l}\text { Years of the supplier company in the market } \\
\text { from its foundation. }\end{array}$} \\
\hline & $\begin{array}{l}\text { Quality Process } \\
\text { Certification }\end{array}$ & \multicolumn{2}{|c|}{$\begin{array}{l}\text { Certifications of the } \\
\text { quality of the } \\
\text { process followed by } \\
\text { the supplier } \\
\text { company given by } \\
\text { recognized certification } \\
\text { authorities. }\end{array}$} & $\begin{array}{l}\text { Qualification: } \\
\text { (Good, Correct, } \\
\text { Suitable) } \\
\\
\text { Derived } \\
\text { attribute }\end{array}$ \\
\hline & & CMM Level & \multicolumn{2}{|c|}{$\begin{array}{l}\text { Capability Maturity Model } \\
\text { Level granted to the } \\
\text { supplier company }\end{array}$} \\
\hline & & ISO 9000 & \multicolumn{2}{|c|}{$\begin{array}{l}\text { ISO } 9000 \text { Certificate } \\
\text { granted to the supplier } \\
\text { company. }\end{array}$} \\
\hline & & $\begin{array}{l}\text { Other } \\
\text { Certificates }\end{array}$ & \multicolumn{2}{|c|}{$\begin{array}{l}\text { Other quality process } \\
\text { certificates }\end{array}$} \\
\hline & $\begin{array}{l}\text { Client } \\
\text { Recommendations }\end{array}$ & \multicolumn{3}{|c|}{$\begin{array}{l}\text { References and recommendations of the } \\
\text { supplier company that other clients have } \\
\text { given. }\end{array}$} \\
\hline
\end{tabular}

Table 4. Excerpt of the extended NT-ISO/IEC catalogue (grey: subcharacteristics; white: attributes).

\subsection{Customized NT-ISO/IEC Catalogues}

Since the extended NT-ISO/IEC catalogue is quite comprehensive (144 non-technical factors), we have needed just a few additions to tailor it to our experiences. On the other hand, it is more likely that some factors belonging to the catalogue are not interesting, or need a slight redefinition (e.g., a particular metrics is required). For example, in the experience reported in [11], the metrics of the attribute Direct Support was redefined in order to know not just if it is provided and its description, but also the list of channels of direct support provided by the supplier (mail, phone, messenger, ...).

\section{Using Catalogues in COTS Selection}

COTS selection in public companies is often driven by call for tenders processes. In these processes the company elaborates a document that consists on a wish-list about the COTS to select, which is sent to 
potential suppliers inviting them to submit their products for their consideration during the selection.

Our catalogues may be used to facilitate the writing of complete enough call for tenders documents (named Request for Information Forms, RFI), to make easier the analysis of the answers of the potential suppliers, and to support the negotiation process.

RFI contents are requirements stated as constraints on the attributes included in the customized ISO/IEC and customized NT-ISO/IEC catalogues. Answers of suppliers consist of values (or interval of values) given to the attributes for the COTS proposed, using the stated metrics. Once the company obtains the answers from the clients, the common framework offered by the catalogues makes easier the identification of mismatches among COTS components characteristics and the stated requirements.

\section{Conclusions}

In this paper we have presented an approach for dealing with non-technical issues during COTS selection processes. We have aligned technical and non-technical information during COTS selection by using the ISO/IEC 9126-1 catalogue as common framework. This is a crucial benefit since both categories can be assimilated: technical and nontechnical quality factors are diverse but they share some fundamental properties. We have proposed a 3level catalogue of non-technical information, corresponding to three abstraction levels.

Concerning comparison with other works that include a catalogue of non-technical factors $[13,14,15$, 16], the main difference is the number on non-technical quality factors that we have identified in the NTISO/IEC extended model, the way in which they have been organized, and the provision of metrics for evaluating each factor. Our extended NT-ISO/IEC catalogue is much richer than others we know about; it encompasses near 150 non-technical quality factors (including the ones identified in the reviewed approaches) which are arranged in a hierarchical treelike structure, similar to the one proposed in the well known ISO/IEC 9126-1 software quality standard, outlining a uniform framework well-suited for the evaluation of both technical and non-technical quality factors. Also, the way we have presented of integrating technical and non-technical issues is not as explicit as ours. Other works also address the importance nontechnical factors. Among them we remark [17]. The aim of that work is much wider; it provides a complete and comprehensive framework for software process improvement, including support for the elicitation of requirements and the selection of COTS suppliers and components. However, it does not provide a catalogue of non-technical quality factors, it just mentions some relevant categories and examples of them, thus it can be supported by / complemented with our proposal.

\section{Acknowledgments}

This work has been done in the framework of the research project UPIC TIN2004-07461-C02-01.

\section{References}

[1] A. Finkelstein, G. Spanoudakis, K. Ryan. "Software Package Requirements and Procurement". IWSSD'96, Westphalia, 1996.

[2] J. Kontio. "A case study in applying a systematic method for COTS selection". ICSE'96, Berlin, 1996.

[3] B. Wong, D. R. Jeffery. "A Framework for Software Quality Evaluation”. PROFES'02, Rovaniemi, 2002.

[4] D. Kunda. "STACE: Social Technical Approach to COTS Software Evaluation". Book Chapter in ComponentBased Software Quality - Methods and Techniques, LNCS 2693, 2003.

[5] ISO Standard 9126: Software Engineering - Product Quality, part 1. International Organization for Standarization, 2001.

[6] http://www.lsi.upc.es/ gessi/QMTool/CQM/

[7] X. Franch, J.P. Carvallo. "A Quality-Model-Based Approach for Describing and Evaluating Software Packages". RE'02, Essen, 2002.

[8] X. Franch, J.P. Carvallo. "Using quality models in software package selection". IEEE Software, 20(1), 2003.

[9] J.P. Carvallo, X. Franch, C. Quer. "A Quality Model for Requirements Management Tools". Book chapter in Requirem-ents Engineering for Sociotechnical Systems, Idea Group, 2005.

[10] J.P. Carvallo, X. Franch, C. Quer, N. Rodriguez. "A Framework for Selecting Workflow Tools in the Context of Composite Information Systems". DEXA'04, Zaragoza, 2004.

[11] J.P. Carvallo. "Supporting Organizational Induction and Goals Alignment for COTS Components Selection by Means of $i^{* \prime}$. ICCBSS'06, Orlando, 2006.

[12] J.P. Carvallo, X. Franch. "Extending the ISO/IEC 91261 Quality Model with Non-Technical Factors for COTS Components Selection“. WOSQ'06, Shangai, 2006.

[13] D. Kunda, L. Brooks. "Identifying and classifying processes (traditional and soft factors) that support COTS component selection: a case study". European Journal of Information Systems, 9(4), 2000.

[14] A. Powell, A. Vickers, W. Lam. "Evaluating Tools to support Component Based Software Engineering”. SAST'95, Los Alamitos, 1997.

[15] M.F. Bertoa, J.M. Troya, A. Vallecillo. "A Survey on the Quality Information Provided by Software Component Vendors". QAOOSE'03, Darmstadt, 2003.

[16] M. Torchiano, L. Jaccheri, C.-F. Sørensen, A. I. Wang. "COTS products characterization". SEKE'02, Ischia, 2002.

[17] CMMI Product Team. "Capability Maturity Model ${ }^{\circledR}$ Integration $\left(\mathrm{CMMI}^{\mathrm{SM}}\right)$,", Version 1.1. Carnegie Mellon SEI, Pittsburgh, 2002. 